\title{
Review of Value Addition to Raw Copper in Zambia
}

\author{
Christopher Mulunda ${ }^{1}$, Dr. Emmanuel Kabaso Musonda ${ }^{2}$, Dr. Edwin Luwaya ${ }^{3}$
}

\begin{abstract}
Zambia's economy is mining dependent and is mainly negatively affected by the low global copper prices. Zambia is ranked the largest copper producer in Africa and seventh in the world. Zambia produces $70 \%$ of Africa's copper production which is very highvolume production, but in terms of value very low worth, only $0.04 \%$ of world's economy. This is the first stage of Value Addition. Typically, wealth realised out of first stage of Value Addition is very low and that have confined the country in poverty with the national head count poverty line rated at 60.5 per cent. This paper reviews the Value Addition to Copper mineral resource in Zambia. Statistics indicate that Zambia's economy is mainly made of exporting refined copper and raw copper accounting for 68.3\% of Gross Domestic Product. The Gross Domestic Product (GDP) can be increased to the power of two of the current one if the cross-Stage Value Addition was implemented. Zambia could have earned 524.35 billion US Dollars if it had engaged in the production of Litz wire representing $3547.4 \%$ more than she earned. The higher prices of the products in the second and third Stages of Value Addition answer the questions why Zambia has remained poor despite being the leader in the first stage of value addition. The values obtained from the mathematical Model that estimates the worthy of the product if the cross -Stage Value Addition was implemented indicate that value addition to refined copper can turn around Zambia's economy and thereby reducing the National head count poverty line rate which is currently at $60.5 \%$.
\end{abstract}

Keywords: Value Addition, Stage value worth, technology

\section{Introduction}

Zambia's economy is mainly based on mineral exports. Figure 1 illustrates the percentages of mineral products exported by Zambia in the year 2016. Refined Copper (64\%) is the leading Zambia's export product followed by raw Copper $(13 \%)$. In the third position is unprocessed tobacco $(2.2 \%)$. Cobalt $(1.8 \%)$ is the fourth positioned Zambia's export product. Gold $(0.95 \%)$ and precious stones $(0.77 \%)$ are in the fifth and sixth positions, respectively. They are exported as first stage Value Addition products. In comparison with the year 2014 central statistics office data shows that refined copper still tops the list. This trend has not been different over the years. (1)
The World Bank ranks Zambia as the largest copper producer in Africa accounting for 70 per cent of Africa's total copper production and ranks seventh in the world (2).Zambia exports mainly refined copper (representing 64 percent of the total exports of Zambia), followed by raw copper (accounting for 13 per cent) and the fabricated copper products account for 1.5078 per cent. The fabricated copper products include Copper alloys (0.0028\%), Copper wire $(0.74 \%)$, Stranded copper wire $(0.052 \%)$, Copper bars $(0.032 \%)$, Copper plating $(0.65 \%)$, and other miscellaneous copper products $(0.031 \%)$. See figure 3 . (1).

Many other Zambian products either exported as raw or fabricated are in very small quantities listed in table 3 , in the Appendix.

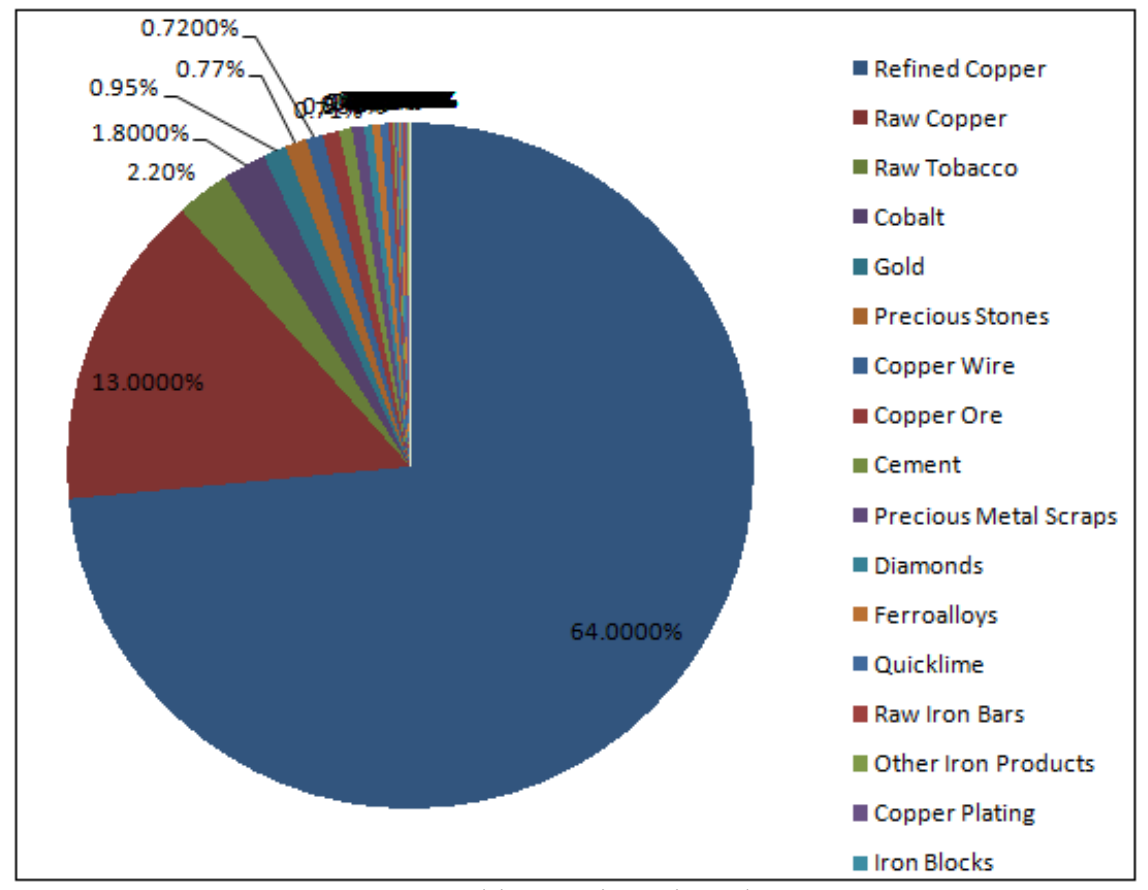

Figure1: Zambia's major mineral exports.

Source: (1)

Volume 6 Issue 7, July 2017

www.ijsr.net

Licensed Under Creative Commons Attribution CC BY 


\section{International Journal of Science and Research (IJSR) \\ ISSN (Online): 2319-7064}

Index Copernicus Value (2015): 78.96 | Impact Factor (2015): 6.391

Value addition analysis

Value addition is the process of enhancing the products or services so that they are worth more because they have been improved or had something added to them. In the context of engineering manufacturing, the three main stages involved in conversion of raw minerals to final products include: -

Stage1. Mining and refinery processes,

Stage2. Metal fabrications such as stranded copper wires, copper plating, and copper bars production.

Stage3. Final finished products such as electrical Gadgets and Appliances, Instruments, Machineries and equipment.

\section{Stage1: Mining and refinery processes}

Stage 1 involves extraction and refinery processes. The metal ore is extracted from the ground and then goes through processes of removing impurities until the actual high quality pure metal is recovered. Value is added to the product by both extracting it from the ground and purifying it to pure metal.

\section{Stage2: Metal fabrications}

This stage includes transforming the refined metal into shapes such as stranded copper wires, insulated copper wires, copper plating, copper bars, alloying and inductor coils.

\section{Stage3: Final finished products}

This stage includes assembly of the components that may have been made in stage 2 into final finished products such as electrical Gadgets and Appliances, Instruments, Machineries and equipment.

\section{Value Addition Stage worth analysis}

Table1 tabulates the value addition of copper from refined copper to Litz wire inductor coil music speaker. When the values are plotted, figure 2 is obtained. The value addition of copper from refined copper to Litz wire music speaker's increases to the power value as the value addition processes progresses from stage 1 to stage 3 as shown in figure 2 . The value addition trend across the stages is estimated by the curve with the coefficient of determination (R- squared) of 0.9974 . Only $0.26 \%$ of estimation is not determinable. The estimation curve's model is represented by equation 1 .

$$
p=6.0117 x^{2.3717} \quad \text { Equation } 1
$$

Where

$\boldsymbol{p}$ - is the price per kilogram of copper at each value addition

\section{Stage}

$\boldsymbol{x}$ - are the stage numbers $(1,2$ and 3$)$

Table 1: Value Addition of copper_ refined copper to Litz wire inductor coil speaker.

\begin{tabular}{|c|c|c|c|c|}
\hline Source: (3) $(4)$ \\
\hline Mineral & $\begin{array}{c}\text { Stage 1 value } \\
\text { (Refined } \\
\text { Copper) }\end{array}$ & $\begin{array}{c}\text { Stage 2 } \\
\text { value } \\
\text { (Litz wire) }\end{array}$ & $\begin{array}{c}\text { Intra stage 2 } \\
\text { (Litz wire } \\
\text { Inductor coil) }\end{array}$ & $\begin{array}{c}\text { Stage 3 value } \\
\text { (Litz wire } \\
\text { Inductor coil } \\
\text { music speaker }\end{array}$ \\
\hline Copper & $\$ 5.80 / \mathrm{kg}$ & $\$ 29.94 / \mathrm{kg}$ & $\$ 90.14 / \mathrm{kg}$ & $\$ 151.40 / \mathrm{each}$ \\
\hline
\end{tabular}

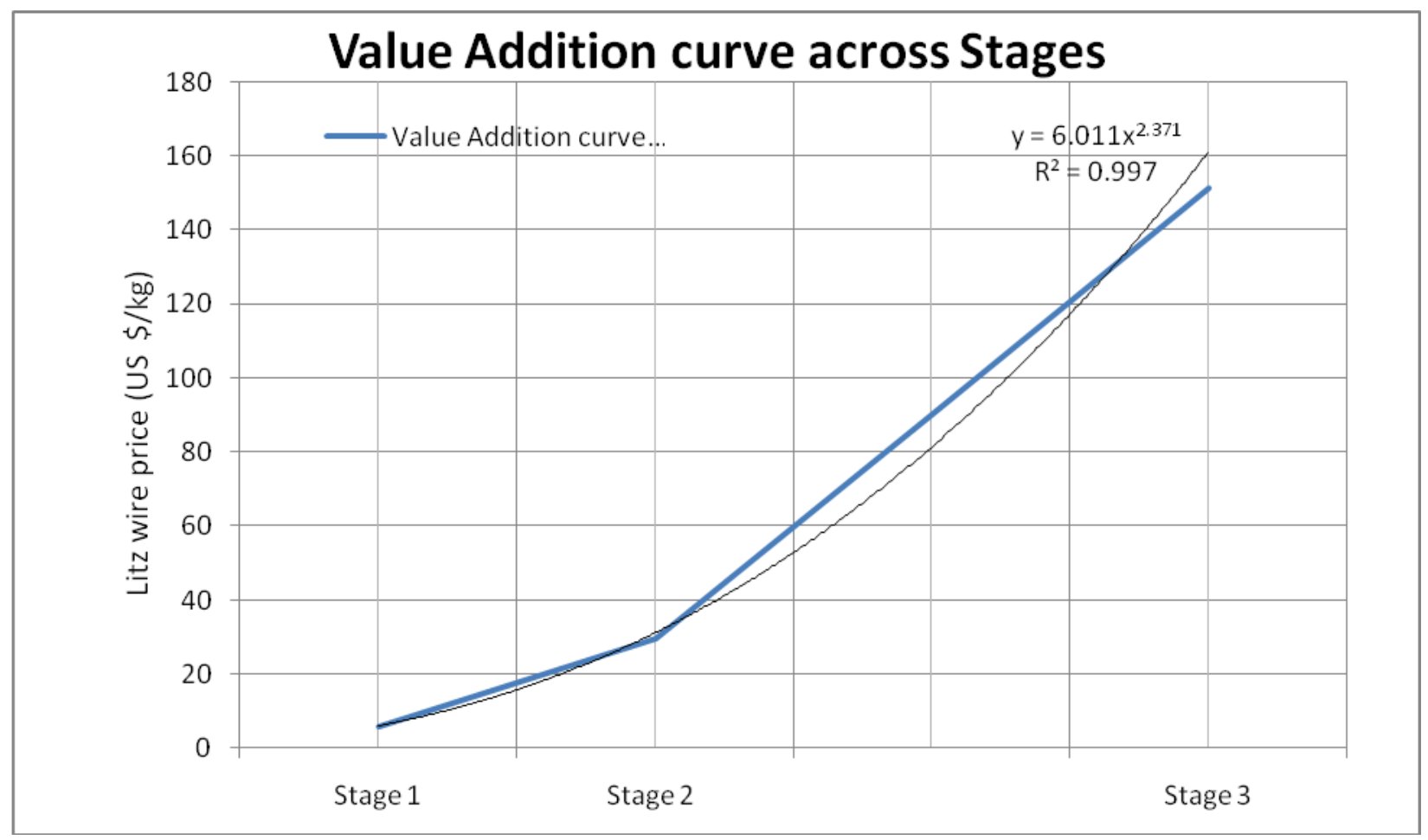

Figure 2: Value addition of Copper from refined Copper to Litz wire music speaker

\section{Copper plating}

Value addition through copper plating can have dual benefits like in the example of Hospital Bed railing. First, the cost of railing hospital bedrails raises the worth of refined Copper to about US $\$ 60$ to US $\$ 100$ per bed. Second, reduce the healthcare acquired infection since copper kills bacteria, Yeasts and viruses. In the study conducted at Medical University of South Carolina in the United States of America the results show that the presence of copper bed 


\section{International Journal of Science and Research (IJSR) \\ ISSN (Online): 2319-7064 \\ Index Copernicus Value (2015): 78.96 | Impact Factor (2015): 6.391}

rails reduced the number of healthcare acquired infections from $8.1 \%$ in regular rooms to $3.4 \%$ in the copper rooms. (5) Copper can reduce the disease burden of Zambia and increases the nation's GDP.
Zambia's position in the Copper Value Addition Stages

The Figure 3 illustrates Zambia's participation in the Copper mineral conversion stages. She participates $68.3 \%$ in mining and refinery, $1.5078 \%$ in Copper fabrication and zero per cent in the lucrative stage, the machinery or equipment production stage.

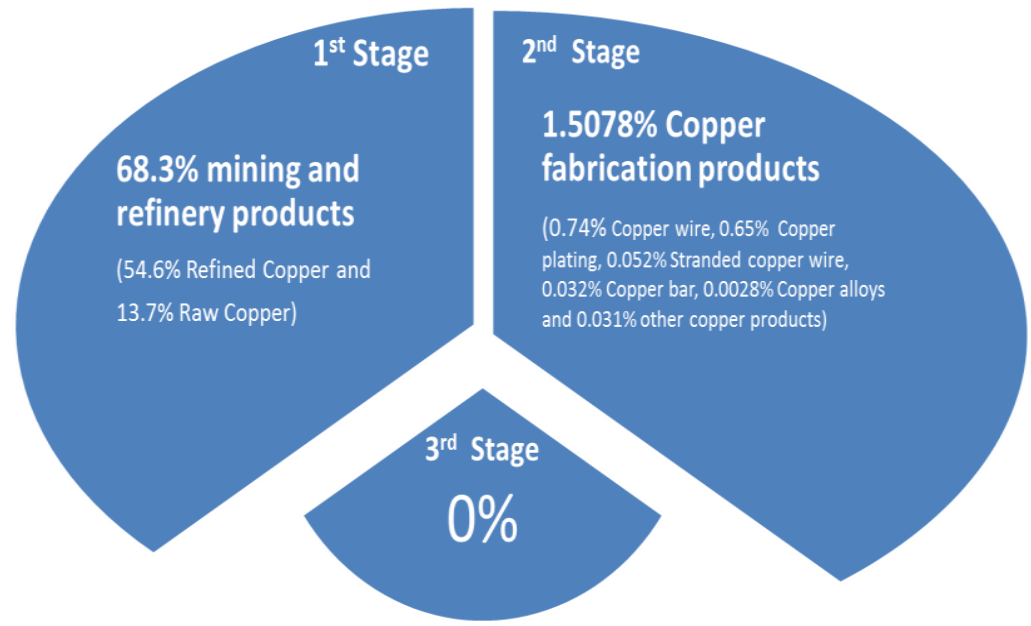

Figure 3: Mineral conversion stages

\section{Value Addition verses poverty}

The statistics in figure2 indicate that Zambia's economy is mainly made of exporting refined copper and raw copper accounting for 68.3 per cent of Zambia's Gross Domestic Product (GDP). The GDP in the year 2014 was 26.97 billion United States of America (USA) dollars representing 0.04 per cent of the world economy. See figure3. (2)The 54.6per cent of 26.97 billion US Dollar is 14.78 billion US dollars was earned representing 2.463 million metric tons of refined copper: Copper price being US 6,000.00 dollars per metric ton or US $\$ 6.00$ per kilogram.

Table 2 tabulates the prices of stranded copper wires. On average the stranded copper wires costs US \$ 218.86 per kilogram, subtracting the refined copper price (US $\$ 6.00$ per kilogram) it accounts for US \$212.86 per kilogram as value addition. Zambia could have earned 524.35 billion US dollars representing $3547.7 \%$ more than she earned just by stranding the refined Copper. It is therefore, urged that value addition to copper can turn around Zambia's economy and thereby reduce the national head count poverty line rate which is currently at 60.5 per cent. Zambians suffers from high poverty levels due to lack of technologies that can add value to its mineral resources by converting them into finished products. New Technologies are faster and produce high quality products. Developing and implementing value addition technologies such as Induction furnaces, which are the primary processes of stranding technologies, can convert Zambia's mineral resources into finished high valued exportable products and reduce poverty levels. The production volume levels will not only be high but also the worth of the products will be high. Earning more per production volume is the essence of value addition technologies.

Table2: Stranded Litz Copper wire prices (6)

\begin{tabular}{|c|c|c|c|c|c|c|c|}
\hline Description & \multicolumn{3}{|c|}{ Dimensions } & Mass & \multicolumn{3}{|c|}{ Rates (US\$) } \\
\cline { 2 - 6 } & Diameter $(\mathrm{mm})$ & Length $(\mathrm{m})$ & Strands & $\mathbf{k g})$ & Per kg & Per Ton & Per piece \\
\hline $\begin{array}{c}\text { Copper wire -braided 0.1 x 120 strands, } \\
\text { 20m/pc multi strand enamelled wire }\end{array}$ & 0.1 & 20 & 120 & 0.1686 & 183.25 & 183,250 & 30.90 \\
\hline $\begin{array}{c}\text { Copper Litz wire 0.1 x 120 Strands,200m/pc } \\
\text { multi strand Litz wire }\end{array}$ & 0.1 & 200 & 120 & 1.6862 & 157.75 & 157,750 & 266.00 \\
\hline $\begin{array}{c}\text { Copper Litz wire-0.1 x 30 Strands, 100m/pc } \\
\text { multi strands Litz wire }\end{array}$ & 0.1 & 100 & 30 & 0.2108 & 142.33 & 142,330 & 30.00 \\
\hline $\begin{array}{c}\text { Copper Litz wire-0.07 x 80 Strands, 100m/pc } \\
\text { multi strands Litz wire }\end{array}$ & 0.07 & 100 & 80 & 0.2754 & 138.00 & 138,000 & 38.00 \\
\hline
\end{tabular}

\section{Value addition verses Technology}

Technological advancement of any country is revealed in its ability to convert the natural resources into more valuable products or services. The appreciation of any investment in research and technology development is through value addition. The relationship between technological advancement and value addition is directly linked. The type of technology determines how raw materials are processed, the quality of the products and how fast the products are produced. Business leaders and policy makers must keep track of more than 60 technologies and philosophies impacting production systems today. The technologies oblige companies to rethink and retool everything they do internally and governments to reassess their national 


\section{International Journal of Science and Research (IJSR) \\ ISSN (Online): 2319-7064 \\ Index Copernicus Value (2015): 78.96 | Impact Factor (2015): 6.391}

competitive advantages and develop strategies. The Chief executives and chief operation officers who embrace these technologies and rapidly transform their enterprises will set their companies on course for success. The government leaders who set the right policies, develop and infuse these technologies, and make ready their workforce, infrastructure and supply chain to leverage them, will position their economies for growth. (7)
Figure 4 shows the variation of Zambia's GDP over ten years. The highest GDP that Zambia ever achieved was in 2014 US\$26.97 Billion. From 2009 The Zambia’s GDP increased slowly due to negative effect of Global price of copper. The Zambia's GDP growth rate is very much dependent on Global copper price.

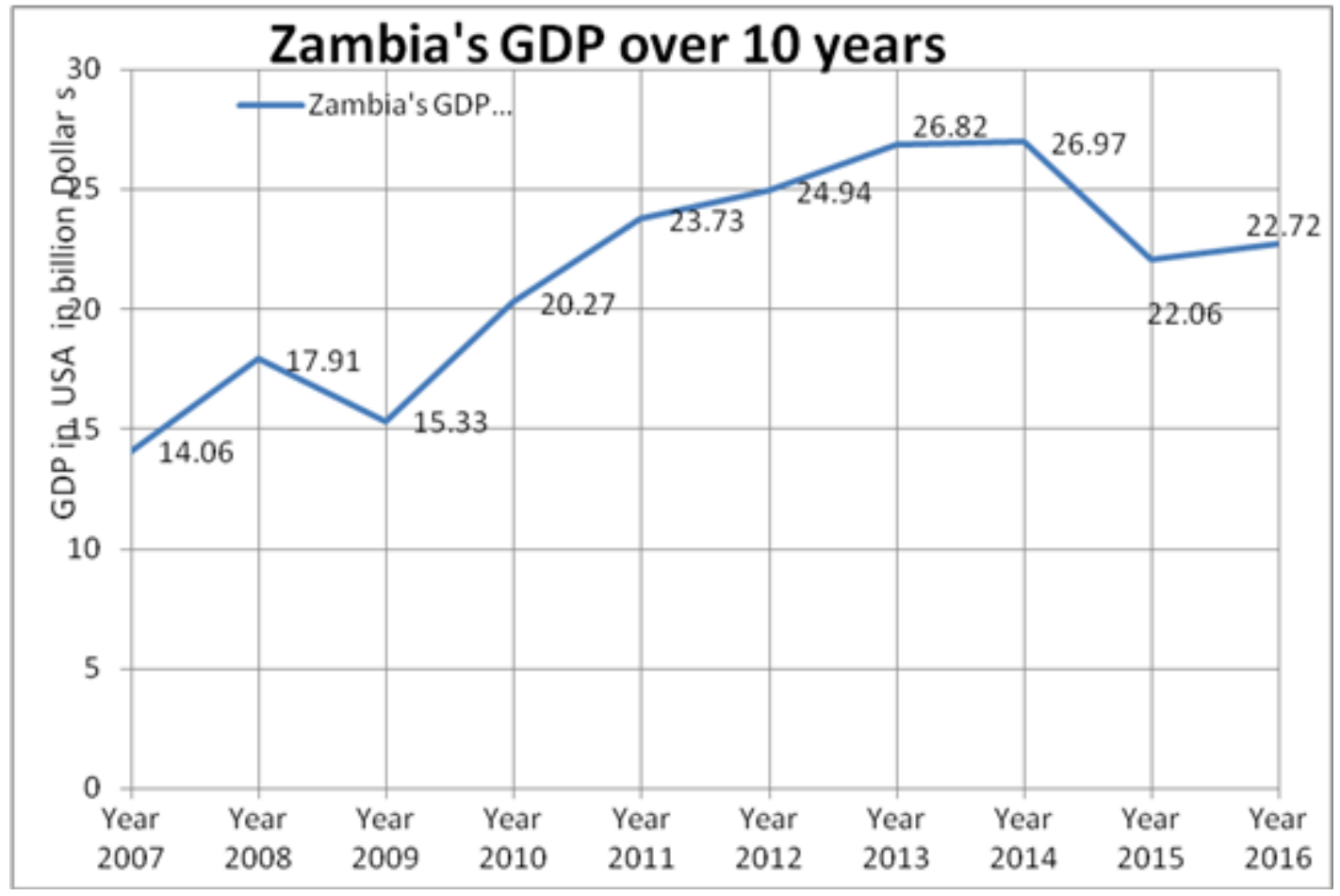

Figure 4: Gross Domestic Product Zambia over the past 10 Years, Source: (8)

\section{Conclusiom and Recommendations}

\section{Conclusion}

The following conclusions have been observed from the research:

1) Zambia participates more in the first stage and very litle in the second stage of Value addition. There is negligible or zero participation in the third stage of value addition.

2) The prices of the third stage products are very high in comparison to the products in the second and first stages of value addition. As a result Zambia that participates mainly in the first stage has low income despite having vey high production volumes.

3) Since the worth of the products is very low the porverty levels have remained high.

\section{Recommendations}

The following recommendations arise from review of Value Addition to mineral resources in Zambia:-

1) In the resent past Zambia has worked very hard in increasing copper production levels, but the GDP realised from the sales has not been commesurate with the amount of hard working or effort put in. This is due to the low prices dominant in the first stage of Value Addition. It is therefore reccomended that more investments be made in the research and develeopment of value addition technologies that can enable Zambia increase participation in the second stage and cross over to third stage of Value Addition.

2) The intra second stage participation will be easier to venture into. Instead of selling Zamefa products as they are sold, investment should be made in converting copper wires to litz wire inductor coils for instance.

3) Curriculum from first grade to university must be tailored to address value addition challenges.

\section{References}

[1] OEC-Zambia Exports, Imports, and Trade Partners. [Online] [Cited: June 15, 2017.] http:/atlas.media.mit.edu/en/profile/country/zmb/.

[2] World Bank. Data. New Yoke : s.n., 2014.

[3] Solen TM. solen TM online. Solen TM. [Online] June 15, 2017. [Cited: June 15, 2017.] https:/solen.ca/product-category/inductors.

[4] London Metal Exchange. LME Copper. London Metal Exchange. [Online] June 15, 2017. [Cited: June 15, 2017.] www.lme.com/metals/non-ferrous/copper/.

[5] Copper Surface Reduce the Rate of HealthcareAcquired Infections in the Intensive Caer unit. Cassandra D, at .,al. 5, South Carolina: Cambridge 


\section{International Journal of Science and Research (IJSR) \\ ISSN (Online): 2319-7064 \\ Index Copernicus Value (2015): 78.96 | Impact Factor (2015): 6.391}

Univeeersity Press, May 5, 2013, Infection Prevention and Hospital Epidemiology, Vol. 34 , pp. 479-486. 8.

[6] AliExpress. AliExpress TM. AliExpress TM. [Online] June 15, 2017. [Cited: June 15, 2017.] www.aliexpress.com/premium/copper-litz-wire.html.

[7] Leurent, H. at, al. Technology and Innovation for the Future of Production: Accelerating Value creation. Cologny : World , 2017.
[8] World Bank. Trading economics. Zambia GDP. [Online] November 23, 2016. https://tradingeconomics.com/zambia/gdp.

[9] Zambia Central statistical office. Lusaka : s.n., 2013.

[10]Zambia GDP . [Online] 1960 -2017. [Cited: June 15, 2017.] https:/tradingeconomics.com/zambia/gdp.

Appendix

Table 3: Products exported by Zambia. Source: (1)

\begin{tabular}{|c|c|c|c|c|}
\hline Product Exported & Export Value & Export RCA & Percent & HS92 ID \\
\hline Refined Copper & $\$ 8.04 \mathrm{~B}$ & 206 & $64.0000 \%$ & 7403 \\
\hline Raw Copper & $\$ 1.68 \mathrm{~B}$ & 299 & $13.0000 \%$ & 7402 \\
\hline Raw Tobacco & $\$ 283 \mathrm{M}$ & 32.6 & $2.2000 \%$ & 2401 \\
\hline Cobalt & $\$ 232 \mathrm{M}$ & 172 & $1.8000 \%$ & 8105 \\
\hline Gold & $\$ 119 \mathrm{M}$ & 2.32 & $0.9500 \%$ & 7108 \\
\hline Precious Stones & $\$ 97.3 \mathrm{M}$ & 39.9 & $0.7700 \%$ & 7103 \\
\hline Copper Wire & $\$ 91 \mathrm{M}$ & 3.31 & $0.7200 \%$ & 7408 \\
\hline Copper Ore & $\$ 89.7 \mathrm{M}$ & 2.37 & $0.7100 \%$ & 2603 \\
\hline Cement & $\$ 66.3 \mathrm{M}$ & 3.23 & $0.5300 \%$ & 2523 \\
\hline Precious Metal Scraps & $\$ 58.3 \mathrm{M}$ & 5.61 & $0.4600 \%$ & 7112 \\
\hline Diamonds & $\$ 48.1 \mathrm{M}$ & 14.3 & $0.3800 \%$ & 7102 \\
\hline Ferroalloys & $\$ 40 \mathrm{M}$ & 2.37 & $0.3200 \%$ & 7202 \\
\hline Quicklime & $\$ 39.6 \mathrm{M}$ & 124 & $0.3100 \%$ & 2522 \\
\hline Raw Iron Bars & $\$ 23.5 \mathrm{M}$ & 1.042 & $0.1900 \%$ & 7214 \\
\hline Other Iron Products & $\$ 11.3 \mathrm{M}$ & 4.96 & $0.0900 \%$ & 7326 \\
\hline Copper Plating & $\$ 11 \mathrm{M}$ & 2.82 & $0.0880 \%$ & 7409 \\
\hline Iron Blocks & $\$ 9.48 \mathrm{M}$ & 1.54 & $0.0750 \%$ & 7216 \\
\hline Stranded Copper Wire & $\$ 9.42 \mathrm{M}$ & 6.53 & $0.0750 \%$ & 7413 \\
\hline Raw Lead & $\$ 9.35 \mathrm{M}$ & 3.26 & $0.0740 \%$ & 7801 \\
\hline Hot-Rolled Iron & $\$ 7.23 \mathrm{M}$ & 0.14 & $0.0580 \%$ & 7208 \\
\hline Coated Flat-Rolled Iron & $\$ 5.16 \mathrm{M}$ & 0.76 & $0.0410 \%$ & 7210 \\
\hline Scrap Copper & $\$ 4.09 \mathrm{M}$ & 0.22 & $0.0330 \%$ & 7404 \\
\hline Copper Bars & $\$ 3.27 \mathrm{M}$ & 0.59 & $0.0260 \%$ & 7407 \\
\hline Interchangeable Tool Parts & $\$ 2.89 \mathrm{M}$ & 0.31 & $0.0230 \%$ & 8207 \\
\hline Other Steel Bars & $\$ 1.75 \mathrm{M}$ & 0.87 & $0.0140 \%$ & 7228 \\
\hline Aluminium Wire & $\$ 1.53 \mathrm{M}$ & 4.82 & $0.0120 \%$ & 7605 \\
\hline PRODUCT EXPORTED & Export Value & Export RCA & Percent & HS92 ID \\
\hline Iron Structures & $\$ 1.5 \mathrm{M}$ & 0.096 & $0.0120 \%$ & 7308 \\
\hline Garden Tools & $\$ 1.17 \mathrm{M}$ & 4.67 & $0.0093 \%$ & 8201 \\
\hline Zinc Powder & $\$ 1.09 \mathrm{M}$ & 2.78 & $0.0087 \%$ & 7903 \\
\hline Other Hand Tools & $\$ 1.06 \mathrm{M}$ & 0.89 & $0.0084 \%$ & 8205 \\
\hline Metal Stoppers & $\$ 1.03 \mathrm{M}$ & 1.32 & $0.0082 \%$ & 8309 \\
\hline Other Stainless teel Bars & $\$ 839 \mathrm{k}$ & 0.46 & $0.0067 \%$ & 7222 \\
\hline Iron Fasteners & $\$ 822 \mathrm{k}$ & 0.053 & $0.0065 \%$ & 7318 \\
\hline Other Iron Bars & $\$ 798 \mathrm{k}$ & 0.39 & $0.0064 \%$ & 7215 \\
\hline Flexible Metal Tubing & $\$ 673 \mathrm{k}$ & 0.54 & $0.0054 \%$ & 8307 \\
\hline Scrap Aluminium & $\$ 516 \mathrm{k}$ & 0.052 & $0.0041 \%$ & 7602 \\
\hline Other Small Iron Pipes & $\$ 506 \mathrm{k}$ & 0.037 & $0.0040 \%$ & 7306 \\
\hline Cast Iron Pipes & $\$ 506 \mathrm{k}$ & 0.34 & $0.0040 \%$ & 7303 \\
\hline Precipitated Copper & $\$ 472 \mathrm{k}$ & 1.005 & $0.0038 \%$ & 7401 \\
\hline Coated Metal Soldering Products & $\$ 434 \mathrm{k}$ & 0.25 & $0.0035 \%$ & 8311 \\
\hline Hot-Rolled Iron Bars & $\$ 422 \mathrm{k}$ & 0.12 & $0.0034 \%$ & 7213 \\
\hline Lead Sheets & $\$ 364 \mathrm{k}$ & 1.6 & $0.0029 \%$ & 7804 \\
\hline Stranded Iron Wire & $\$ 347 \mathrm{k}$ & 0.066 & $0.0028 \%$ & 7312 \\
\hline Iron Pipe Fittings & $\$ 356 \mathrm{k}$ & 0.024 & $0.0028 \%$ & 7307 \\
\hline Iron Sheet Piling & $\$ 296 \mathrm{k}$ & 0.27 & $0.0024 \%$ & 7301 \\
\hline Iron Gas Containers & $\$ 289 \mathrm{k}$ & 0.12 & $0.0023 \%$ & 7311 \\
\hline Aluminium Pipes & $\$ 283 \mathrm{k}$ & 0.11 & $0.0023 \%$ & 7608 \\
\hline Aluminium Plating & $\$ 249 \mathrm{k}$ & 0.062 & $0.0020 \%$ & 7606 \\
\hline
\end{tabular}

Volume 6 Issue 7, July 2017 www.ijsr.net

Licensed Under Creative Commons Attribution CC BY 
International Journal of Science and Research (IJSR)

ISSN (Online): 2319-7064

Index Copernicus Value (2015): 78.96 | Impact Factor (2015): 6.391

\begin{tabular}{|l|l|l|l|l|} 
Titanium & $\$ 230 \mathrm{k}$ & 0.074 & $0.0018 \%$ & 8108 \\
\hline Iron Pipes & $\$ 228 \mathrm{k}$ & 0.013 & $0.0018 \%$ & 7304 \\
\hline Scrap Iron & $\$ 198 \mathrm{k}$ & 0.015 & $0.0016 \%$ & 7204 \\
\hline Raw Aluminium & $\$ 192 \mathrm{k}$ & 0.0055 & $0.0015 \%$ & 7601 \\
\hline Iron Chains & $\$ 173 \mathrm{k}$ & 0.072 & $0.0014 \%$ & 7315 \\
\hline PRODUCT EXPORTED & Export Value & Export RCA & Percent & HS92 ID \\
\hline Stainless Steel Ingots & $\$ 163 \mathrm{k}$ & 0.63 & $0.0013 \%$ & 7218 \\
\hline Razor Blades & $\$ 155 \mathrm{k}$ & 0.048 & $0.0012 \%$ & 8212 \\
\hline Other Lead Products & $\$ 139 \mathrm{k}$ & 0.5 & $0.0011 \%$ & 7806 \\
\hline Iron Ingots & $\$ 133 \mathrm{k}$ & 0.19 & $0.0011 \%$ & 7206 \\
\hline Aluminium Housewares & $\$ 130 \mathrm{k}$ & 0.022 & $0.0010 \%$ & 7615 \\
\hline Iron Springs & $\$ 113 \mathrm{k}$ & 0.027 & $0.0009 \%$ & 7320 \\
\hline Other Aluminium Products & $\$ 94.9 \mathrm{k}$ & 0.053 & $0.0008 \%$ & 7616 \\
\hline Wrenches & $\$ 106 \mathrm{k}$ & 0.085 & $0.0008 \%$ & 8204 \\
\hline Large Coated Flat-Rolled Iron & $\$ 85.1 \mathrm{k}$ & 0.084 & $0.0007 \%$ & 7212 \\
\hline Small Iron Containers & $\$ 85.7 \mathrm{k}$ & 0.027 & $0.0007 \%$ & 7310 \\
\hline
\end{tabular}

Volume 6 Issue 7, July 2017 www.ijsr.net

Licensed Under Creative Commons Attribution CC BY 